\title{
立坑シールド工法における坑底部掘削土砂の挙動に 関する理論的考察
}

\author{
THEORETICAL CONSIDERATION ON THE BEHAVIOR OF EXCAVATED SOILS \\ IN A VERTICAL SHIELD EXCAVATIONG METHOD
}

\author{
高橋 弘 ${ }^{1} \cdot$ 松井 二郎 ${ }^{2} \cdot$ 田村 克己 $^{3}$ \\ Hiroshi TAKAHASHI, Jiro MATSUI and Katsumi TAMURA
${ }^{1}$ 正会員 工博 東北大学助教授 工学研究科地球工学専攻（T980-8579 仙台市青葉区荒巻字青葉 01）
2 東北大学大学院工学研究科地球工学専攻博士前期訸程（同上） \\ 3 日立建機株式会社 研究開発セン夕（テ300-0013 土浦市神立町 650)
}

\begin{abstract}
In order to apply the vertical shield machine for the construction of the large diameter vertical shaft, a new mechanism to carry the excavated particles on the excavated surface is necessary because the direction of excavation is equal to the direction of gravity. In the previous study, a new method to carry the excavated by the rotating wall-jet particles from the initial position to the bottom center of the vertical shaft was proposed and model experiments were carried out. In this study, the behavior of excavated particles was analyzed theoretically. It was confirmed through the analysis of the behavior of water jet and excavated particles at the bottom of the vertical shaft that the water jet in air is desirable and the cutter spoke should have an inclination angle.
\end{abstract}

Key Words: Vertical Shield Machine, Excavated Particles, Rotating Wall-Jet, Particle Trajectory

\section{1.はじめに}

一般に大口径の立坑を掘削する場合, 地中に壁を造り， 立坑の周囲を鉄板などで覆い, 内部をパワーショベルな どで掘り下げる「地中連続壁工法」が採用されることが 多い". しかし，この工法には多大な建設コストが必要 であるとともに, 連続壁の構築に厳しい精度が要求され るため, 掘削機械のオペレー夕は常に連続的な緊張を強 いられるという欠点がある. 一方, トンネルなどの横坑 掘削ではシールド工法が広く用いられており, 現在では カッター面板の方向制御のみならず, セグメントの組立 も自動化されている2).そこで, 大深度大口径の立坑掘 削に横坑掘削では既に多くの実績のあるシールド工法 を適用することが考えられる.この立坑シ一ルド工法が 可能になれば，機械自体を低空頭（長さが短い）・軽量 化できるため, 初期の発進工事が簡単になり, またセグ メントの組立も自動化が可能であることから, 工期の大 幅な短縮と建設コストの削減が期待できる.

この立坑シールド工法を実現するにあたり, 最大の 問題点は繰粉(掘削時に岩盤が破砕されて生じる岩石 粒子. 以下，掘削粒子と記す) を如何にして坑外に排出 するかである. 横坑シールドでは重力の方向と進行方 向が直交しているため, 掘削粒子はチャンバー下部に 集中する. 従って, この部分に排泥管を設置し, ポン プで坑外に排出すればよい. しかし, 立坑シールドで は重力の方向と進行方向が一致しているため, 何らか の排泥機構を設置しなければ，円滑な排泥は期待でき ない.すなわち, 実現されれば大きなメリットが期待
できる立坑シールド工法であるが，その成否は掘削粒 子の排出機構の確立にあると言っても過言ではない.

著者らは，噴流による掘削粒子の搬送を考え，図-1 に示すような立坑シールド掘進機を想定して, 既に模 型実験を行った. その結果, 掘削粒子は主として噴流 の最も流速の速い部分で搬送され，また坑底面では気 中液噴流が発生するように送水流量および排出流量を 調整すべきであることを確認した ${ }^{3)}$.

本研究では, 坑底面における噴流および掘削粒子の 挙動について理論的に考察し, 立坑シールド工法にお ける排泥機構の確立の一助とすることを目的とする.

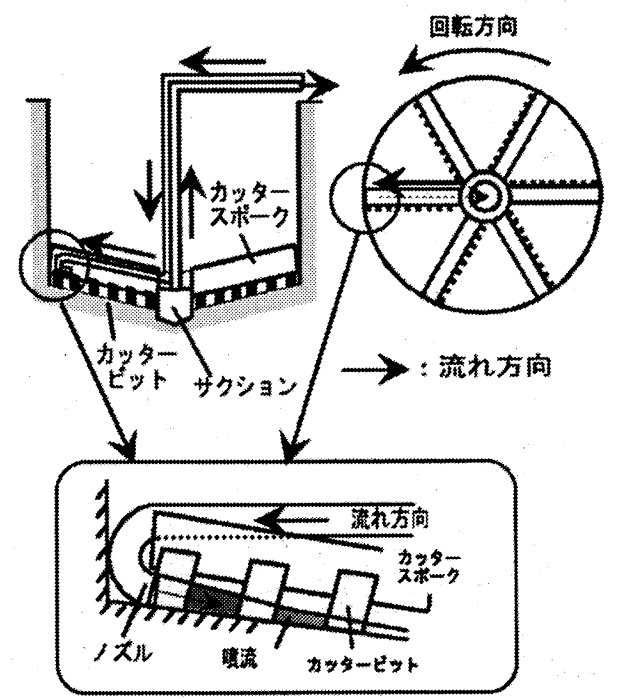

図-1 提案する立坑シールド工法 


\section{2. 噴流の速度分布について}

ここでは坑底部における気中液噴流について考察を 行う。ノズルから噴出される噴流は，広がりながら流 下するので, 噴流全体について考察することが望まし い. しかし，坑底面はすり鉢状になっており，噴流は その面に沿って流下する，いわゆる壁面噴流になり， さらに回転成分を有するため噴流全体の速度分布を考 察することはかなり難しい．また掘削粒子は主として 噴流の最も速度の速い部分で搬送され，その速度の速 い部分から掘削粒子が外れると, 粒子はすぐにその位 置に停止してしまうことが実験により確認された。 つ まり周辺の噴流は, 掘削粒子の搬送にはほとんど寄与 していない. そこで, ここではノズル吐出口の中心軸 を通る鉛直面を含む単位幅領域より噴出する微少流体 塊の挙動を基に, 最大流速について検討する.つまり, 坑底面上に広がる噴流中心部近傍の最も流速の速い部 分について考察する.

ノズルは坑底面の鉛直上方にあるため流体塊はノズ ルから放出された後, 坑底面に向かって自由落下する. 流体塊は坑底面に衝哭した後, 坑底面の摩摖を受けな がら中心部方向に流下する. 噴流の流れの状態として 図-2 に示すように 4 つの領域に分割して検討を行う.

I : ノズルの下端より微少流体塊が放出され，その鈶 直上方にはノズルがある領域

II : ノズルの上端より微少流体塊が放出された直後か ら, Iにおいてノズルの下端から放出された微少 流体塊が坑底部に衝突するまでの領域

III : ノズルの下端から放出された微少流体塊が坑底面 に落下した地点から，噴流の厚みがほぼ一定にな る地点までの領域

$\mathrm{IV}:$ III以降の領域

まず領域 I においてノズルの下端から放出される微 少部分の速度について検討する. 座標系を図-3に示す ように定義する. 図中の L はカッタースポークの長さ を示す.ノズルの下端の X, Z の初期座標を $\left(\mathrm{X}_{01}, Z_{01}\right)$ とす る. ノズルの下端から噴出される噴流の微少部分の自 由落下に関する運動方程式は, 次のようになる.

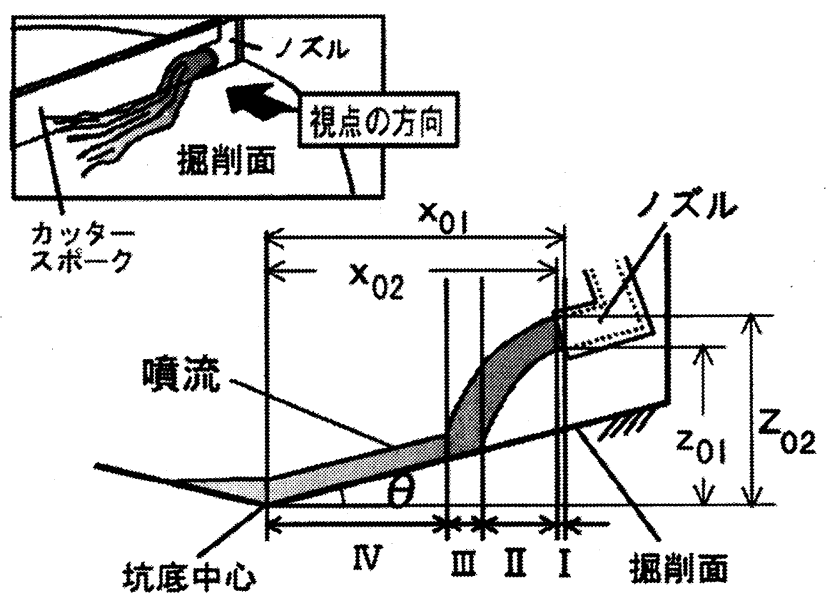

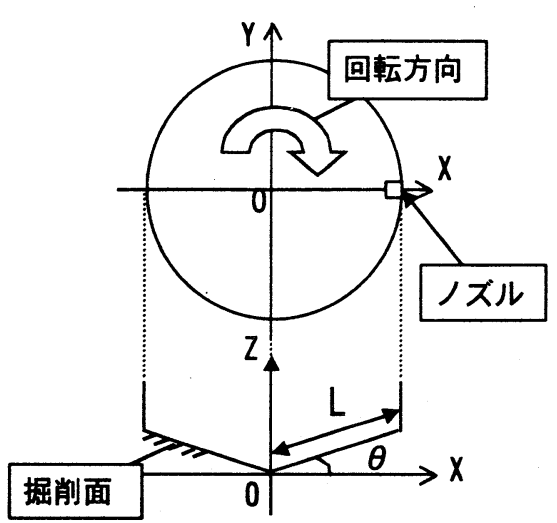

图-3 座標軸の定義

$$
m \frac{d u_{l}}{d t}=0, \quad m \frac{d v_{l}}{d t}=0, \quad m \frac{d w_{l}}{d t}=-m g
$$

$\mathrm{m}$ は微少流体塊の質量, $\mathrm{u}_{\mathrm{l}}, \mathrm{v}_{1}$ および $\mathrm{w}_{1}$ はそれぞれ $\mathrm{X}, \mathrm{Y}$ および $Z$ 方向の噴流速度, $\mathrm{g}$ は重力加速度である. 微少 流体塊のX方向の初速度は，「送水流量をノズルの断面 積で除して得られる賁流の $\mathrm{X}$ 方向の初速度 $\mathrm{V}_{\mathrm{x} x \mathrm{O}}$ 」に等し く, Y 方向の初速度は, 中心軸からノズル口の下端まで の距離 $\mathrm{x}_{01}$ とカッタースポークの回転速度 $\omega$ の積 $\mathrm{x}_{01} \omega$ で与えられる. また $Z$ 方向の初速度は 0 である.

領域Iにおいてノズルの上端から噴出される噴流の 微少部分の自由落下に関する運動方程式は，(1)式と同 様に次式で与えられる.

$$
m \frac{d u_{h}}{d t}=0, \quad m \frac{d v_{h}}{d t}=0, \quad m \frac{d w_{h}}{d t}=-m g
$$

$\mathrm{u}_{\mathrm{h}}, \mathrm{v}_{\mathrm{h}}$ および $\mathrm{w}_{\mathrm{h}}$ は, $\mathrm{X}, \mathrm{Y}$ およびZ方向の噴流速度である. また微少流体塊の X 方向の初速度は，I と同様に「送 水流量をノズルの断面積て除して得られる噴流の X 方 向の初速度 $\left.\mathrm{V}_{\mathrm{V} \mathrm{x} x}\right\rfloor$ に等し<, $\mathrm{Y}$ 方向の初速度は, 中心軸 からノズルロの上端までの距離 $\mathrm{x}_{02}$ とカッタースポーク の回転速度 $\omega$ の積 $\mathrm{x}_{02} \omega$ で与えられる. また $Z$ 方向の初 速度は0である.

IIIおよびTの領域では, 開水路におけるエネルギー 方程式を基に噴流速度について検討する ${ }^{4)}$ 。この領域 においては, 坑底面から噴流の上端までの鉛直方向距 離を水深 $\mathrm{h}$ とすると, 図-4 に示すように座標 $\mathrm{X}, \mathrm{Y}$ にお ける，坑底中心部を基準面とする流れのエネルギーH は次式で与えられる。

$$
H=\frac{u^{2}+v^{2}+w^{2}}{2 g}+\frac{P}{\rho_{w} g}+z
$$

ここに，u, v, w はそれぞれ噴流の微少流体塊の X, Y, Z 方向の速度, $\mathrm{P}$ は圧力, $\rho_{\mathrm{v}}$ は流体の密度である. 本研 究で対象とする気中液噴流については, 圧力分布は静 水圧分布であると仮定すると, 圧力ヘッドは水深 $\mathrm{h}$ を 用いて次式で表される.

$$
P / \rho_{w} g=h+s-z
$$

ここで, $\mathrm{s}$ は坑底面の高さである. 従って, (3)式は次 式のように表される.

図-2 噴流の模式図 


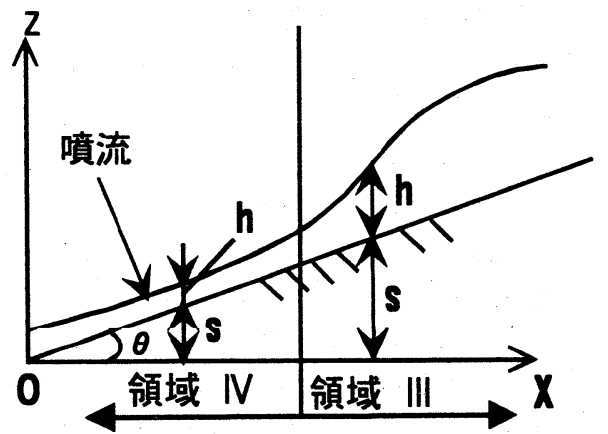

図-4 領域III, IVにおける噴流の模式図

$$
H=\frac{u^{2}+v^{2}+w^{2}}{2 g}+h+s
$$

（5）式の左辺および右辺第 1 項を s から h まで, 右辺第 2 項を基準面から h まで, 右辺第 3 項を基準面から s まで積分する. また左辺, 右辺第 1 項および第 2 項を $\mathrm{h}$ で, 右辺第 3 項を s でそれぞれ除して各項の断面平均 をとると次式が得られる.

$$
\begin{aligned}
\int \frac{H d z}{h} & =\int \frac{u^{2}+v^{2}+w^{2}}{2 g h} d z+\int \frac{h d z}{h}+\int \frac{s d z}{s} \\
& =\int \frac{u^{2}+v^{2}+w^{2}}{2 g h} d z+h+s
\end{aligned}
$$

(6) 式の右辺の第 1 項は次式のように変形できる.

$$
\int \frac{u^{2}+v^{2}+w^{2}}{2 g h} d z=\frac{\beta_{x} V_{f x}{ }^{2}+\beta_{y} V_{f y}{ }^{2}+\beta_{z} V_{f z}{ }^{2}}{2 g}
$$

$\mathrm{V}_{\mathrm{fx}}, \mathrm{V}_{\mathrm{fy}}$ および $\mathrm{V}_{\mathrm{f} z}$ はそれぞれ $\mathrm{X}, \mathrm{Y}$ および $\mathrm{Z}$ 方向の流体 の平均断面流速であり，これが噴流の微少流体塊の速 度である. $\beta_{x}, \beta_{y}$ および $\beta_{z}$ は次式で表される係数で ある.

$$
\beta_{x}=\frac{\int u^{2} d z}{V_{f x}^{2} h}, \beta_{y}=\frac{\int v^{2} d z}{V_{f y}^{2} h}, \beta_{z}=\frac{\int w^{2} d z}{V_{f z}^{2} h}
$$

$\beta_{\mathrm{x}}$ および $\beta_{\mathrm{y}}$ は流体の速度分布が対数分布の場合ほぼ 1 となる. $Z$ 方向の平均断面流速である $\mathrm{V}_{\mathrm{fz}}$ に関しては その検討例が見受けられないため, $\beta_{\mathrm{z}} \mathrm{V}_{\mathrm{fz}}{ }^{2}$ をノズルの 上端から放出される微少流体塊の Z 方向速度 $w_{\mathrm{h}}$ および 補正値 $\alpha$ を用いて次式のように改めて定義する.

$$
\beta_{z} V_{f z}^{2}=\alpha^{2} w_{h}^{2}
$$

$Z$ 方向における噴流速度は, 坑底部に接するところで 0 であり，水表面において最大值をとる. 水深が大きい ときに断面全体の $Z$ 方向速度を考えると坑底部付近の 速度は無視することができるとして $\alpha$ はほぼ1になる.

改めて断面平均のエネルギーを $\mathrm{H}$ とすると(6)式は (11) 式のように表される.

$$
\begin{gathered}
\int H d z / h=H \\
H=\frac{\beta_{x} V_{f x}^{2}+\beta_{y} V_{f y}^{2}+\alpha^{2} w_{h}^{2}}{2 g}+h+s
\end{gathered}
$$

（11）式を X, Y, Z 方向にそれぞれ偏微分すると，(12)式, (13)式および(14)式がそれぞれ得られる.

$$
\begin{aligned}
\frac{\partial H}{\partial x} & =\frac{\beta_{x} V_{f x}}{g} \frac{\partial V_{f x}}{\partial x}+\frac{\beta_{y} V_{f y}}{g} \frac{\partial V_{f y}}{\partial x}+\frac{\alpha^{2} w_{h}}{g} \frac{\partial w_{h}}{\partial x}+\frac{\partial h}{\partial x}+\frac{\partial s}{\partial x} \\
& =\frac{\beta_{x} V_{f x}}{g} \frac{\partial V_{f x}}{\partial x}+\frac{\beta_{y} V_{f y}}{g} \frac{\partial V_{f y}}{\partial y} \frac{\partial y}{\partial x}+\frac{\alpha^{2} w_{h}}{g} \frac{\partial w_{h}}{\partial x}+\frac{\partial h}{\partial x}+\frac{\partial s}{\partial x} \\
\frac{\partial H}{\partial y} & =\frac{\beta_{x} V_{f x}}{g} \frac{\partial V_{f x}}{\partial y}+\frac{\beta_{y} V_{f y}}{g} \frac{\partial V_{f y}}{\partial y}+\frac{\alpha^{2} w_{h}}{g} \frac{\partial w_{h}}{\partial y}+\frac{\partial h}{\partial y}+\frac{\partial s}{\partial y} \\
& =\frac{\beta_{x} V_{f x}}{g} \frac{\partial V_{f x}}{\partial x} \frac{\partial x}{\partial y}+\frac{\beta_{y} V_{f y}}{g} \frac{\partial V_{f y}}{\partial y}+\frac{\alpha^{2} w_{h}}{g} \frac{\partial w_{h}}{\partial y}+\frac{\partial h}{\partial y}+\frac{\partial s}{\partial y}
\end{aligned}
$$

$$
\begin{aligned}
\frac{\partial H}{\partial z} & =\frac{\beta_{x} V_{f x}}{g} \frac{\partial V_{f x}}{\partial z}+\frac{\beta_{y} V_{f y}}{g} \frac{\partial V_{f y}}{\partial z}+\frac{\alpha^{2} w_{h}}{g} \frac{\partial w_{h}}{\partial z}+\frac{\partial h}{\partial z}+\frac{\partial s}{\partial z} \\
& =\frac{\alpha^{2} w_{h}}{g} \frac{\partial w_{h}}{\partial z}
\end{aligned}
$$

(14)式において, $\mathrm{V}_{\mathrm{fx}}, \mathrm{V}_{\mathrm{fy}}$ は断面平均の速度のため, $\partial \mathrm{V}_{\mathrm{fx}} /$ $\partial \mathrm{z}, \quad \partial \mathrm{V}_{\mathrm{fy}} / \partial \mathrm{z}$ は 0 とする. 一方, マニングの式を用 いると, エネルギー勾配 I と単位幅あたりの流量 q の 関係は次式で表される.

$$
\begin{aligned}
& q=\frac{h^{5 / 3} I^{1 / 2}}{N}, \quad I=\frac{q^{2} N^{2}}{h^{10 / 3}} \\
& q=h{\sqrt{V_{f x}^{2}+V_{f y}^{2}}}^{2}
\end{aligned}
$$

ここでN は粗度係数である. エネルギ一勾配 I は流体 の進行方向に負の值をとる. 微少流体柱は X, Z 方向に は負の方向に進み，Y方向には正の方向に進むため, I は次式で表される.

$$
I=\frac{\partial H}{\partial x}-\frac{\partial H}{\partial y}+\frac{\partial H}{\partial z}
$$

また，連続の式は次式で表される.

$$
\frac{\partial V_{f x}}{\partial x}+\frac{\partial V_{f y}}{\partial y}+\alpha \frac{\partial w_{h}}{\partial z}=0
$$

(12)式ないし(18)式より次式が得られる.

$\frac{\partial V_{f x}}{\partial x}=\frac{K_{1}}{K_{2}}$

$K_{1}=I+\frac{\alpha \beta_{y} V_{f y}}{g} \frac{\partial w_{h}}{\partial z}\left(\frac{\partial y}{\partial x}-1\right)-\frac{\alpha^{2} w_{h}}{g}\left(\frac{\partial w_{h}}{\partial x}-\frac{\partial w_{h}}{\partial y}+\frac{\partial w_{h}}{\partial z}\right)$

$$
-\left(\frac{\partial h}{\partial x}+\frac{\partial s}{\partial x}\right)+\left(\frac{\partial h}{\partial y}+\frac{\partial s}{\partial y}\right)
$$

$K_{2}=\frac{\beta_{x} V_{f x}}{g}\left(1-\frac{\partial x}{\partial y}\right)+\frac{\beta_{y} V_{f y}}{g}\left(1-\frac{\partial y}{\partial x}\right)$

$\frac{\partial V_{f y}}{\partial y}=\frac{K_{3}}{K_{4}}$

$K_{3}=I-\frac{\alpha \beta_{x} V_{f x}}{g} \frac{\partial w_{h}}{\partial z}\left(\frac{\partial x}{\partial y}-1\right)-\frac{\alpha^{2} w_{h}}{g}\left(\frac{\partial w_{h}}{\partial x}-\frac{\partial w_{h}}{\partial y}+\frac{\partial w_{h}}{\partial z}\right)$

$$
-\left(\frac{\partial h}{\partial x}+\frac{\partial s}{\partial x}\right)+\left(\frac{\partial h}{\partial y}+\frac{\partial s}{\partial y}\right)
$$

$K_{4}=-\frac{\beta_{x} V_{f x}}{g}\left(1-\frac{\partial x}{\partial y}\right)-\frac{\beta_{y} V_{f y}}{g}\left(1-\frac{\partial y}{\partial x}\right)$

（19）式および(20) 式を基に領域III～IVにおける噴流の 
微少流体柱の速度を求める.

さて, $\mathrm{X}$ 方向の水深の変化は, 紙面の関係上詳細は省 略するが，すり鉢状の坑底形状などを考慮に入れ，次 式を算出した.

$$
\begin{aligned}
\partial h / \partial x & =K_{5} / K_{6} \\
K_{5}= & \frac{h\left(h-h_{1}\right) \tan \theta}{\sqrt{h^{2}+2 x h \tan \theta}}+\frac{h_{1} h \tan \theta}{\sqrt{h_{1}{ }^{2}+2 x h_{1} \tan \theta}} \\
K_{6}= & \frac{(h+x \tan \theta)\left(h_{1}-h\right)}{\sqrt{h^{2}+2 x h \tan \theta}}-\sqrt{h^{2}+2 x h \tan \theta} \\
& -\sqrt{h_{1}{ }^{2}+2 x h_{1} \tan \theta}
\end{aligned}
$$

また, $\mathrm{Y}$ 方向の水深の変化は次式により得られる.

$$
\frac{\partial h}{\partial y}=-\frac{\partial s}{\partial y}=-\frac{y \tan \theta}{\sqrt{x^{2}+y^{2}}}
$$

坑底の高さ $s$ およびその坑底勾配は，それぞれ次式で 表される.

$$
\begin{gathered}
s=\tan \theta \sqrt{x^{2}+y^{2}} \\
\frac{\partial s}{\partial x}=\frac{x \tan \theta}{\sqrt{x^{2}+y^{2}}}, \frac{\partial s}{\partial y}=\frac{y \tan \theta}{\sqrt{x^{2}+y^{2}}}
\end{gathered}
$$

次に $Z$ 方向の速度について検討する. IIIの領域にお いて, $Z$ 方向の速度 $w_{h}$ は，(2)式を積分することにより 得られる. IVの領域においては， $w_{h}$ に関する項は以下 の様に定義する．ただし，本領域では噴流の厚さは薄 く, ほぼ一定と考え, $\mathrm{z}$ を独立変数 $\mathrm{x}, \mathrm{y}$ および傾斜角 $\theta$ の関数とする.

$\frac{\partial z}{\partial x}=\frac{\partial h}{\partial x}+\frac{\partial s}{\partial x}, \quad w_{h}=\frac{\partial z}{\partial t}=\frac{\partial z}{\partial x} \frac{\partial x}{\partial t}, \quad \frac{\partial w_{h}}{\partial x}=\frac{\partial}{\partial x}\left(\frac{\partial z}{\partial x} \frac{\partial x}{\partial t}\right)$ $\frac{\partial w_{h}}{\partial y}=\frac{\partial}{\partial y}\left(\frac{\partial z}{\partial y} \frac{\partial y}{\partial t}\right), \frac{\partial w_{h}}{\partial z}=\frac{\partial}{\partial z}\left(\frac{\partial z}{\partial x} \frac{\partial x}{\partial t}\right)$

カッタースポークの傾斜角 $\theta$ が 0 度の場合には, $\partial \mathrm{h} /$ $\partial \mathrm{x}, \partial \mathrm{s} / \partial \mathrm{x}, \partial \mathrm{z} / \partial \mathrm{x}$ および $\partial \mathrm{z} / \partial \mathrm{y}$ は 0 となる. ま た，断面全体の $Z$ 方向速度を考えるとIVの領域では水 深が非常に小さくなり，坑底部付近の速度は無視する ことができなくなるため， $\alpha$ に適切な值を用いる必要 がある. 本研究では, この $\alpha$ の值を理論的に求めるこ とは困難であったため, 先に報告した実験結果と計算 結果がなるべく一致するように, $\alpha=0.1$ と仮定した. 以上で検討した諸式を(19)式および(20) 式に代入して IIIおよびTの領域における噴流の微少流体柱の速度 $\mathrm{V}_{\mathrm{fx}}$ および $V_{\mathrm{fy}}$ を差分法により計算し, $V_{f}=\sqrt{V_{f x}^{2}+V_{f y}^{2}}$ より

噴流速度 $\mathrm{V}_{\mathrm{f}}$ を算出した.

計算結果の一例を図-5 示す。計算に用いた条件は, 既に行われた実験条件と同じに設定した. すなわち， 立坑の直径を $0.5 \mathrm{~m}$, カッタースポークの傾斜角を 0 度 および 10 度, カッタースポークの回転数を 2.1 および $2.8 \mathrm{rpm}$, 送水流量を $2.6,3.2$ および $3.8 \times 10^{-5} \mathrm{~m}^{3} / \mathrm{s}$ と した.ここでは, 実験結果との比較検討を通して本モ デルの妥当性を検討するため, 傾斜角は 0 度および 10 度の 2 通りで計算した. 先に報告した実験では, 掘削 土砂の排出という点からは, カッタースポークに傾斜
角をつけた方がよいという結論を得たが，カッタース ポークの傾斜角が大きすぎると機械自体の長さが大き くなり, 初期の発進工事のコストを軽減するメリット が失われてしまう. そこで, カッタースポークには傾 斜角をつけるものの, 可能な限り小さくする必要があ る. 10 度は傾斜角の最大值と考えられるため, 本計算 においても 0 度 10 度の 2 通りで計算を行った.

さて，図中の実験点は，噴流に混ぜたトレ一サ一粒 子(比重 0.96 , 直径約 $2 \mathrm{~mm}$ の球形ポリスチレン粒子)の 速度をプロットしたものである. 比重がほぼ1であり, 直径も $2 \mathrm{~mm}$ 程度であるので, トレーサー粒子はほぼ流 体に追従して運動すると考え，このトレーサ一粒子の 速度を噴流の速度にほぼ等しいと考える. すなわち， 実験点は，噴流が広がっている全範囲内の噴流速度を 示している. 噴流は, X-Y 平面内で速度分布を有すると ともに, Z方向にも速度分布を有するが, 本研究では, Z 方向に対しては, 断面内で平均した代表流速で考察し ている. 噴流の広がり方向には速度分布があるが，そ の分布の中で最大流速の部分しか掘削土砂の搬送に寄 与していないので, 本研究では横方向の噴流の広がり の中で最大流速の部分についてのみ考察した. 従って, 計算值は，実験值が分布している上限を示せばほぼ妥 当ということになるが，図中の実線で示される噴流速 度の計算結果は, 実験值が分布している範囲の上限に ほぼ一致しており，噴流内の最大流速を表していると 考えられ，本モデルはほぼ妥当と考察される.

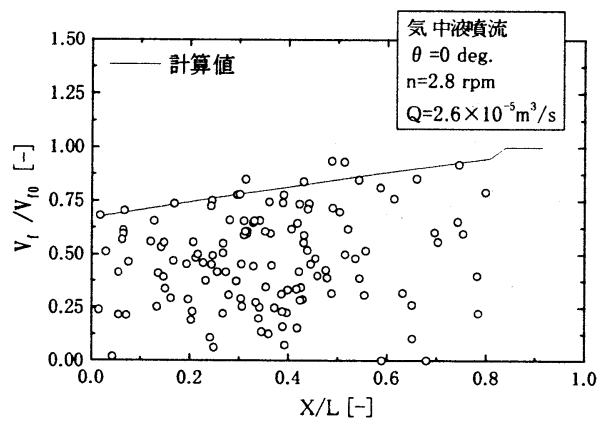

図-5 噴流速度の実験値と計算値との比較

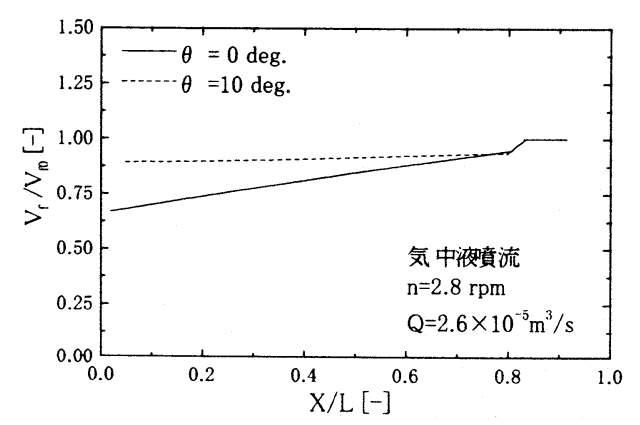

図-6 噴流速度に及ぼすカッタースポークの傾斜角の影響

図6 は, カッタースポークの角度, すなわち坑底面 の角度が 0 度および 10 度の場合における噴流速度の計 算値の比較を示したものである. 傾斜角 10 度の場合は, 
坑底中心に向かう噴流の平均速度はあまり減少せず, 掘削粒子の搬送には非常に有効であると考えられる.

\section{3. 単一掘削粒子の挙動}

ここでは噴流中の単一掘削粒子の挙動について考察 する. 簡単のため, 粒子を球と仮定し, 噴流領域 I IVのうち，I およびIの領域では噴流が坑底面に接し ていないため，掘削粒子は運搬されないとする. 図一7 に示すように粒子に衝突するX およびY 方向の噴流の 速度を $\mathrm{V}_{0 \mathrm{x}}, \mathrm{V}_{0 \mathrm{y}}$ とする. また, それぞれの方向の流体抗 力を $\mathrm{F}_{\mathrm{D} x}$ および $\mathrm{F}_{\mathrm{D} y}$ とし，それぞれの方向の摩擦力を $\mathrm{F}_{\mathrm{fx}}$ および $\mathrm{F}_{\mathrm{fy}}$ とし, 粒子に作用する重力成分を $\mathrm{F}_{\mathrm{gg}}$ および $\mathrm{F}_{\mathrm{gy}}$ とすると, $\mathrm{X}$ および $\mathrm{Y}$ 方向の粒子の運動方程式はそ れぞれ次式で示される.

$$
\begin{aligned}
& (\pi / 6) d_{s}^{3} \rho_{s}\left(d V_{s x} / d t\right)=F_{D x}+F_{g x}-F_{f x} \\
& (\pi / 6) d_{s}^{3} \rho_{s}\left(d V_{s y} / d t\right)=F_{D y}+F_{g y}-F_{f y}
\end{aligned}
$$

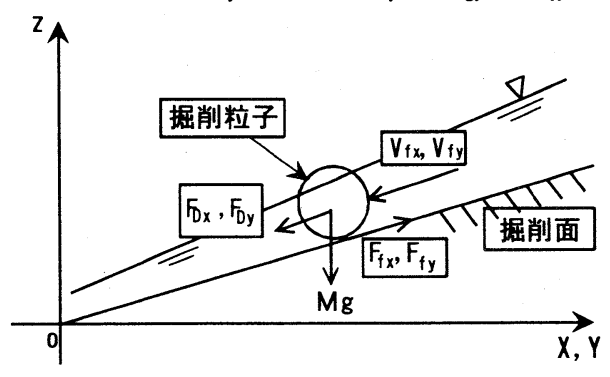

图-7 掘削粒子に作用する力

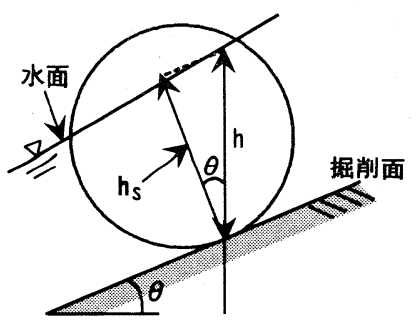

図-8 掘削粒子に衝乫する噴流の水深

ここに, $\mathrm{V}_{\mathrm{sx}}, \mathrm{V}_{\mathrm{sy}}$ はそれぞれ掘削粒子の $\mathrm{X}$ および $\mathrm{Y}$ 方向 の速度, $\mathrm{d}_{\mathrm{s}}$ は粒子の直径, $\rho_{\mathrm{s}}$ は粒子密度である. ここ で，水深について考慮すると，図-8に示すように，前 章で求めた噴流速度のモデルにおける水深 $\mathrm{h}$ は, 掘削 面の法線方向とは一致しない，そこで粒子に対する噴 流の水深 $\mathrm{h}_{\mathrm{s}}$ を次式で近似する.

$$
h_{s}=h \cos \theta
$$

日は坑底面の傾斜角度, すなわちカッタースポークの角 度である. 噴流中にある粒子の流れ方向への投影面積 を $\mathrm{A}_{\mathrm{s}}$ とし，また噴流中の粒子体積を $\mathrm{V}$ とする. 水深 $\mathrm{h}_{\mathrm{s}}$ が $\mathrm{h}_{\mathrm{s}} \geqq \mathrm{d}_{\mathrm{s}}$ の場合, $\mathrm{A}_{\mathrm{s}}$ およびVは次式で表される.

$$
\begin{aligned}
& A_{s}=\left(\pi d_{s}^{2} / 4\right) \\
& V=\left(\pi d_{s}{ }^{3} / 6\right)
\end{aligned}
$$

$\mathrm{h}_{\mathrm{s}}<\mathrm{d}_{\mathrm{s}}$ の場合は, $\mathrm{A}_{\mathrm{s}}$ に対しては次の 2 通りに分けて考え る.
1) $\mathrm{h}_{\mathrm{s}}>\mathrm{d}_{\mathrm{s}} / 2$ の場合 :

$$
A_{s}=\frac{\pi d_{s}^{2}}{4} \frac{(2 \pi-\psi)}{2 \pi}+\frac{1}{2}\left(\frac{d_{s}}{2}\right)^{2} \sin \psi
$$

2) $\mathrm{h}_{\mathrm{s}} \leqq \mathrm{d} / 2$ の場合 :

$$
A_{s}=\frac{\pi d_{s}^{2}}{4}\left\{1+\frac{(2 \pi-\psi)}{2 \pi}\right\}-\frac{1}{2}\left(\frac{d_{s}}{2}\right)^{2} \sin \psi
$$

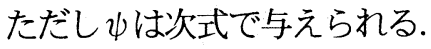

$$
\psi=\arccos \left[\left\{\frac{d_{s}^{2}}{4}-4 h_{s} \frac{d_{s}}{2}+2 h_{s}^{2}\right\} / \frac{d_{s}^{2}}{4}\right]
$$

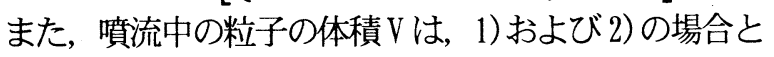
もに, 次式で与えられる.

$$
V=\pi\left[\left(d_{s} h_{s}^{2} / 2\right)-\left(h_{s}^{3} / 3\right)\right]
$$

さて, 流体抗力 $\mathrm{F}_{\mathrm{Dx}}, \mathrm{F}_{\mathrm{Dy}}$ および重力成分と摩擦力との 差はそれぞれ以下の式で表される。

$$
\begin{gathered}
F_{D x}=C_{D}\left(\rho_{f} / 2\right)\left(V_{0 x}-V_{s x}\right)^{2} A_{s} \\
F_{D y}=C_{D}\left(\rho_{f} / 2\right)\left(V_{0 y}-V_{s y}\right)^{2} A_{s} \\
F_{g x}-F_{f x}=M g \cos \varphi_{x}\left(\sin \varphi_{x}-\mu \cos \varphi_{x}\right) \\
F_{g y}-F_{f y}=M g \cos \varphi_{y}\left(\sin \varphi_{y}-\mu \cos \varphi_{y}\right) \\
M=\rho_{s}\left(\pi d_{s}{ }^{3} / 6\right)-\rho_{w} V
\end{gathered}
$$

ただし， $\rho_{1}$ は流体の密度， $C_{D}$ は抗力係数， $\mu$ は粒子と 掘削面との間の摩擦係数である. また $\varphi_{\mathrm{x}}$ および $\varphi_{y}$ は 次式で与えられる.

$$
\varphi_{x}=\arctan (\partial s / \partial x) \quad \varphi_{y}=\arctan (\partial s / \partial y)
$$

従って, 粒子の運動方程式は次式のようになる.

$$
\begin{aligned}
\frac{d V_{s x}}{d t} & =\left(\frac{6}{\pi d_{s}^{3} \rho_{s}}\right)\left\{C_{D} \frac{\rho_{w}}{2}\left(V_{0 x}-V_{s x}\right)^{2} A_{s}\right. \\
& \left.-M g \cos \varphi_{x}\left(-\sin \varphi_{x}+\mu \cos \varphi_{x}\right)\right\} \\
\frac{d V_{s y}}{d t} & =\left(\frac{6}{\pi d_{s}^{3} \rho_{s}}\right)\left\{C_{D} \frac{\rho_{w}}{2}\left(V_{0 y}-V_{s y}\right)^{2} A_{s}\right. \\
& \left.-M g \cos \varphi_{y}\left(-\sin \varphi_{y}+\mu \cos \varphi_{y}\right)\right\}
\end{aligned}
$$

(41) 式および(42) 式中の $\mathrm{V}_{0 \mathrm{x}}$ および $\mathrm{V}_{0 \mathrm{y}}$ は, 掘削粒子の 位置におけるX方向およびY方向の噴流の速度である. こころで, 掘削粒子の位置乞噴流の最大流速の位置が 一致する場合, 前章で求めた $\mathrm{V}_{\mathrm{fx}}$ および $\mathrm{V}_{\mathrm{fy}}$ を用いて, $\mathrm{V}_{0 \mathrm{x}}=\mathrm{V}_{\mathrm{fx}}, \mathrm{V}_{\mathrm{O}}=\mathrm{V}_{\mathrm{fy}}$ としてよい. しかし, 掘削粒子の位置は, 必ずしも噴流の最大流速の位置と一致するとは限らな い. そこで, 最大流速の位置からずれた位置での X お よび $\mathrm{Y}$ 方向の噴流速度 $\mathrm{V}_{0 \mathrm{x}}$ および $\mathrm{V}_{0 \mathrm{y}}$ を以下のように仮 定して求めることにした.

図-9に示すように，噴流は進行方向に対して垂直な 断面においては，ノズルの管径 D の距離までは前節で 求めた流体塊の速度すなわち噴流の最大流速を維持す ると仮定する. また，進行方向に垂直な方向の噴流の 幅を $2 \mathrm{~B}$, 進行方向に垂直な断面における噴流の最高速 度を有する領域の中心線からの距離を $\mathrm{x}_{\mathrm{s}}$, その位置に おける水深を $\mathrm{h}_{\mathrm{s} 1}$ とし, $\mathrm{x}_{\mathrm{s}}$ が $\mathrm{D}$ よりも大きい範囲では, 
とする.このとき，B-D を底辺， $\mathrm{h}$ を高さとする三角形 と, $\mathrm{B}-\mathrm{x}_{\mathrm{s}}$ を底辺, $\mathrm{h}_{\mathrm{s} 1}$ を高さとする三角形は相似である から次式が成り立つ.
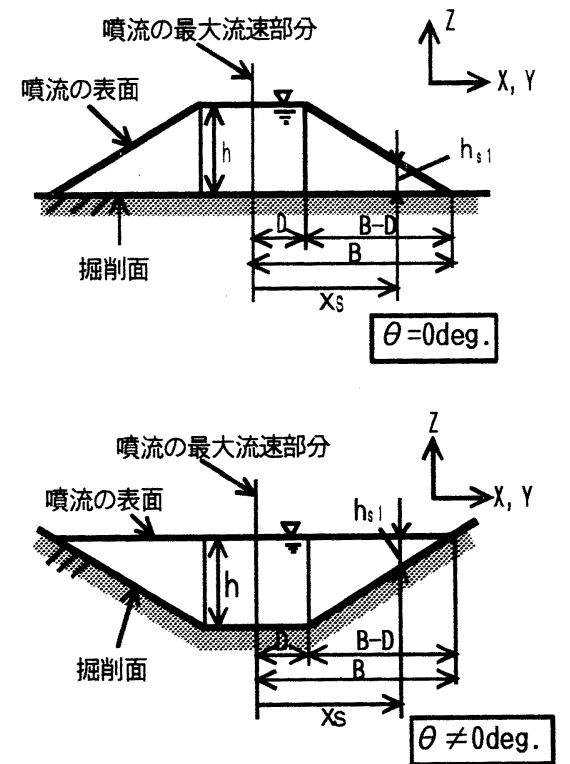

図-9 噴流の広がり方向における水深の模式図

$$
h_{s 1} / h=\left(B-X_{s}\right) /(B-D)
$$

また, 進行方向に対して垂直な断面の面積は, ノズル の断面積と等しいと仮定すると, 噴流の半值幅 B は次 式で与えられる。

$$
B=\left(\pi D^{2} / 4-D h\right)(2 / h)+D
$$

(43)式を(42)式に代入して得られる水深 $h_{51}$ とhの比が, 噴流の最大流䢗とその最大流速を有する位置から進行 方向に対して $x_{s}$ 離れた位置の噴流速度の比に等しいと する. このとき, 最大流速を有する領域の中心線から 進行方向に対して $\mathrm{x}_{8}$ 離れた位置におけるXおよびY 方 向の噴流速度をそれぞれ $V_{0 x}$ および $V_{0 y}$ とし, 以下の式 により算出した.

$$
\begin{aligned}
& V_{0 x}=V_{f x}\left(h_{s 1} / h\right)=\left(B-X_{s}\right) /(B-D) V_{f x} \\
& V_{0 y}=V_{f y}\left(h_{s 1} / h\right)=\left(B-X_{s}\right) /(B-D) V_{f y}
\end{aligned}
$$

以上の諸式を用いて単一掘削粒子速度を計算した. た だし,粒子の直径は実験と同様に $4 \mathrm{~mm}$ および7m とし, 抗力係数は実験を行うにあたり計測した值である 1.3(4m)および $1.25(7 \mathrm{~mm})$ を用いた.また摩擦伱数も同 様に計測した值 $0.67(4 \mathrm{~mm})$ および 0.6(7m $)$ をそのまま 用いた.図-10に掘削粒子速度の実験值と計算値との比 較を示した. 掘削粒子は坑底面上に分布しており, 粒 子速度の実験值と計算值の比較が困難であったため, 粒子の位置が X 軸上に来るように回転移動し, 坑底中 心に向かう半径方向の位置と粒子速度との関係として 図示してある. ここでは, 眓面が煩雑になるので，ノ ズルの出口から坑底中心までの距離を 4 等分する点 3 䇢所に粒子を設定し, 初速度 0 の状態から計算した粒 子速度を示す. 粒子速度は速度 0 の状態から急激に立 ち上がり，下流方向に進むについて減少している. 粒 子速度が 0 になると，その位置で掘削粒子が停止する ことを意味しているため，坑底中心まで搬送されず，
掘削粒子を排出し得ないことになる. 従って, 掘削粒 子速度が坑底中心で 0 以上を示す送水流量を計算によ り求めることにより, 排泥に必要な送水流量を求める ことが可能になると考えられる.

図-11 にカッタースポークの傾斜角度が 0 度および 10 度の場合の気中液噴流における掘削粒子速度の計算 值を示した. 傾斜角が 10 度の場合は，掘削粒子速度は 0から急激に立ち上がった後,粒子速度をほとんど咸少 させることなく下流方向に移動する. 従って, 立坑シ 一ルド掘進機全体の長さは多少長くなってしまうが, カッタースポークは水平よりも傾斜をつけた方が円滑 な排泥という意味では望ましいと結論できる.

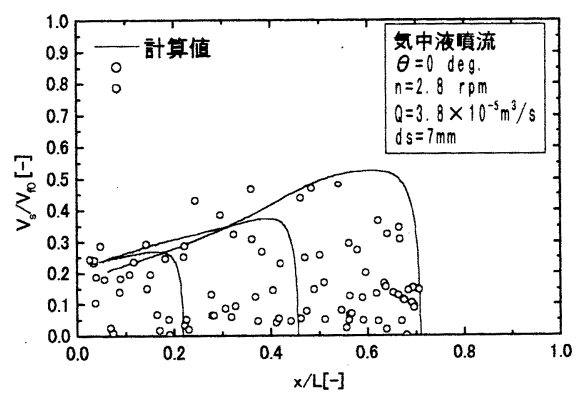

図-10 掘削粒子速度の実験值と計算値との比較

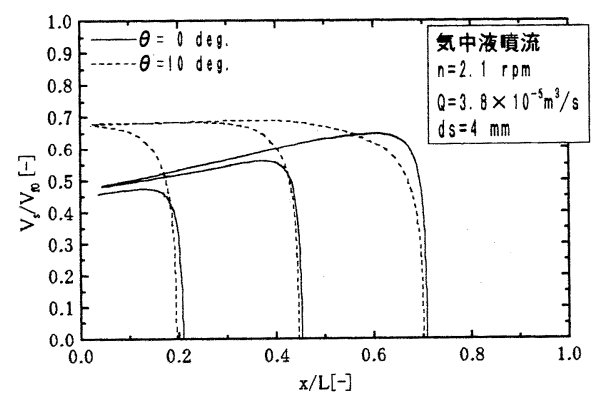

図-11 掘削粒子速度に及ぼすカッタースポーク傾斜角の影響

\section{4.むすび}

坑底面における噴流および掘削粒子の挙動について 理論的に考察を行い, 先に行われた模型実験における 結果との比較検討を行った. その結果, 実験值と計算 值とはほぼ一致し, 本研究で示したモデルはほぼ妥当 であることが確かめられた. 今後は掘削粒子群の挙動 と排泥効率について理論的に考察する予定である.

\section{参考文献}

1)室 達朗ら : 最新建設施工学, 朝倉書店, pp.152-155, 1996.

2)山秝 規安:シールド総合施工管理システムの開発・害用化, 第5回建設ロボットシンポジウム論文集,pp. 273-280, 1995.

3)高橋 弘ら : 新立坑シールド工法における排泥機構に関す 研究, 資源・素材学会春季大会講演集, pp. 63-634, 2000.

4)椎貝 博美: 流体力学ノート6. 開水路の運動方程式, なが れ, Vol.13, pp.241-243,1994.

(2000.10.2 受付) 